Ethiopian Journal of Environmental Studies \& Management 9(Suppl. 2): 1047 - 1058, 2016. ISSN:1998-0507 doi: http://dx.doi.org/10.4314/ejesm.v9i2.10S

Submitted: September 21, 2016

Accepted: December 17, 2016

\title{
SPATIAL VARIATION IN RESIDENTS' ACCESSIBILITY TO LAND FOR HOUSING DEVELOPMENT IN IBADAN METROPOLIS, OYO STATE, NIGERIA
}

\author{
${ }^{*}$ AZEEZ, T., ${ }^{1}$ ADELEYE, $0 .{ }^{2}$ AND OLAYIWOLA, L. ${ }^{2}$ \\ ${ }^{1}$ Department of Urban and Regional Planning, Crescent University, Abeokuta, Ogun \\ State, Nigeria \\ ${ }^{2}$ Department of Urban and Regional Planning, Obafemi Awolowo University, Ile-Ife, \\ Nigeria
}

\begin{abstract}
This study examined the spatial variation in residents' accessibility to land for housing development in Ibadan metropolis, Nigeria. Data for the study were obtained from both primary and secondary sources. A set of questionnaire were designed. The questionnaire targeted the residents' and was administered using systematic random sampling method on household heads living in one out of every twenty fifth (25th) houses located in the six (6) political wards selected in the high, medium and low density residential areas of Ibadan metropolis. A total of 405 household heads were selected for questionnaire administration out of the 10, 703 household heads. Both descriptive and inferential statistical techniques of data analysis were employed. The linear regression results on the spatial variation in residents' level of accessibility to land for housing development showed differences in the level of residents' accessibility where the coefficient of determination $\left(r^{2}\right)$ accounted for $88.8 \%, 88.3 \%$ and $88.1 \%$ variance in the high, medium and low density residential areas respectively. The study concluded that since most land transactions took place outside the formal land use planning mechanism created by the government, land accessibility will improve if special consideration is given to the factors influencing land accessibility in the study area.
\end{abstract}

Key Words: Land accessibility, Spatial variation, Housing development, Ibadan Metropolis

\section{Introduction}

Land has been described by the United Nations (1994) as an area that include all attributes of the biosphere immediately above or below the earth's terrestrial surface, not exempting the soil, terrain, surface hydrology, the nearsurface climate, sediments and associated groundwater reserve, plants and animals, the human settlement pattern and infrastructure resulting from human activity. Therefore, land is a very strategic socio-economic asset, particularly in poor societies where wealth and survival are measured by its control and access. It is also seen as a central element in the varied and complex social relations of production and reproduction within which conflict between individuals and groups are bred (USAID, 2004).

The importance of land to the nation cannot be over-emphasized. This is because it lies at the heart of social, political and economic life of the nation. Along with other resources, it is a key factor for economic growth and 
development of the nation. It is an indisputable source of employment and wealth (Federal Ministry of Housing and Urban Development (FMH and UD) 2006).

In the agricultural sector, land is a fundamental factor of production. It has an essential role to play in increasing as well as sustaining agricultural production. It is therefore the source of livelihood in the rural areas. Land is also at the centre of housing problems in most third world cities, and increasingly so in Nigeria. The scarcity and high cost of land in urban areas has made it become the major obstacle to the adequate provision of affordable urban housing in developing countries (Garba, 1992). Access to land has generally been shown to ensure access to housing for even the poorest households in urban areas of developing countries (Asiama,1990).

In explaining the use to which land could be engaged, two schools of thought are discernible; namely rural land use and urban land use. Rural land use connotes the use of land basically for agriculture, forestry, fisheries, lumbering, livestock and wild life management in the rural area (EU, 2004). On the other hand, urban land use signifies the engagement of land for different purposes such as residential, commercial, industrial, public, semipublic, circulation and recreational in the city (Oduwaye, 2001).

Urban land use for housing development is affected by physical, economic, institutional, social and cultural factors. These factors are accentuated by the rapid and uncontrolled migration, natural increase and urbanization which has resulted in massive pressure on land thereby resulting in high prices for the land available in the market, existing socio-cultural cleavages, lack of secure tenure, inappropriate and inefficient land policies and instruments, weak institutional structures and lack of land management capacity (Bernstein, 2005). These have contributed to current urban land accessibility problems in Nigeria (Djire, 2007; Faye, 2008).

Previous studies on urban land use have concentrated on institutional factor and its relationship with urban land prices and urban land management (Onibokun 1995, Nuhu 2008). Studies of variation in residents' accessibility to urban land for housing development have not been well documented. It is on this note that the study is designed to evaluate the spatial variation in residents' accessibility to land for housing development in different residential densities by positing the case of Ibadan metropolis.

\section{Theoretical Issues}

Land is a unique, valuable, and immovable resource of limited quantity which also contain valuable structures and nature resources on (or beneath) it. According to Jinadu (2004), land is an important factor/or component for national development. Availability of buildable land in terms of ease of acquisition and cost of securing plots influences national development.

In this wise Mabogunje (2000) states that land is one of the most important of our national assets and indeed for any country. Therefore, the two most basic assets of any country are its land and its labour force. Ominrin (2002) supported the view that land is the most important of a nation's asset when he stated that land determines the form in which production is offered as a commodity for consumption. Its location, size and planning status dictate directly or indirectly the form, size and market orientation of the final product.

Accessibility to land is defined as a function of physical, economic and institutional factors. According to Ominrin (2002), accessibility to land comprises of 
availability of usable land, affordability, the convenience with which the cost of the land can be paid without undue financial strain, security of tenure - assurance against eviction, conflicting claims and ease of transaction. Accessibility to land is significant for growth and poverty reduction in any society. In Nigeria, the land use Act of 1978 was promulgated to achieve equal access to land, simplify the management and ownership of land and assist citizenry irrespective of social status to realize aspiration of land ownership.

Despite all efforts to facilitate equitable access to land at reasonable cost, land accessibility by the majority of the urban poor is still a mirage. According to Ominrin (2002), the negative effect of inadequate and inequitable access to land in Nigeria are manifest in inefficient use of land resources, inequitable distribution of wealth, worsened housing condition, environmental degradation, poverty aggravation and regional imbalance in economic development. Mabogunje (2003) documents that the experience of inaccessibility which characterized urban land market have forced most urban dwellers into abject poverty owing to lack of legal titles for securing loans to invest either in construction of desirable shelter or purchase of equipment for economic pursuit.

\section{Land Accessibility and Housing Development}

Housing is recognized worldwide as the second most important basic need of humankind after food. Housing production involves the processes and methods employed to construct or transform inputs like land, labour, capital, physical infrastructure, policies, ideas and information into dwelling units. However, production of housing is constantly challenged by varieties of natural, economic, technical, social, administrative, political and institutional issues.

Land, as one of the major production factors, is indispensable and its accessibility is thus crucial for adequate housing production. However, land is currently not well managed to facilitate housing production at scale due to lack of integration across land administration functions: land tenure, land value, land use and land development (Williamson et al., 2010). The land administration functions and corresponding policies are supposed to interact effectively to facilitate delivery of developable land for housing production but operate much of the time on silo bases which manifest in varying degree of contradictory policy objectives (Egbu et al., 2007; Goodman et al., 2010).

Consequently, the development of housing in most developed and developing countries is impeded (Burns and Dalrymple, 2008; Goodman et al., 2010). The effect of this is manifested in lack of coherent framework to enable effective and efficient utilisation of resources to facilitate housing production. The inefficiency and ineffectiveness increases the cost of housing which makes it largely unaffordable in some contexts (Gurran, 2008).

The low-income earners who lack economic and political power to gain access to urban land in suitable locations for housing construction are experiencing severe land and housing accessibility challenges in sub-Saharan Africa (Okonkwo, 1986). As result of this, majority of urban residents are forced to live in slums and squatter settlements characterized by lack of secured tenure, basic services and general poor housing conditions, which are inimical to human, physical and economic 
development (Oruwari, 2006; Hall 2007; Ademiluyi and Raji, 2008).

\section{Study Area}

Ibadan, the capital of Oyo State is the third largest city in Nigeria by population (after Lagos and Kano), and the largest in geographical area. At independence, Ibadan was the largest and the most populous city in Nigeria and the third in Africa after Cairo and Johannesburg. The city of Ibadan is located approximately on longitude $3^{\circ} 55^{\prime} 00^{\prime \prime}$ East of the Greenwich Meridian and latitude $7^{\circ} 23^{\prime} 47^{\prime \prime}$ North of the Equator at a distance some 145 kilometres Northeast of Lagos. Ibadan is located in southwestern Nigeria about $120 \mathrm{~km}$ east of the border with the Republic of Benin in the forest zone close to the boundary between the forest and the savanna.

There are eleven local governments in Ibadan metropolitan area consisting of five urban local governments in the city and six semi-urban local governments in the less city. The five urban local governments are: Northeast, North Central, Northwest Southeast, and Southwest (See figure 1). Urban cores (high-density) and hinterlands (low-density) characterized Ibadan metropolis. The population of Ibadan metropolis is 2, 550, 593 according to 2006 census. However, its population at 2016 is estimated to be 3.16 million (CIA World Fact, 2016).

The general land use pattern of the Ibadan metropolitan area shows a clear distinction purely residential use. According to Ayeni (1994) residential land use is the most predominant among all land uses in the built up part of Ibadan. The administrative and commercial importance of Ibadan has resulted in land being a key investment, an asset and a status symbol for the population.

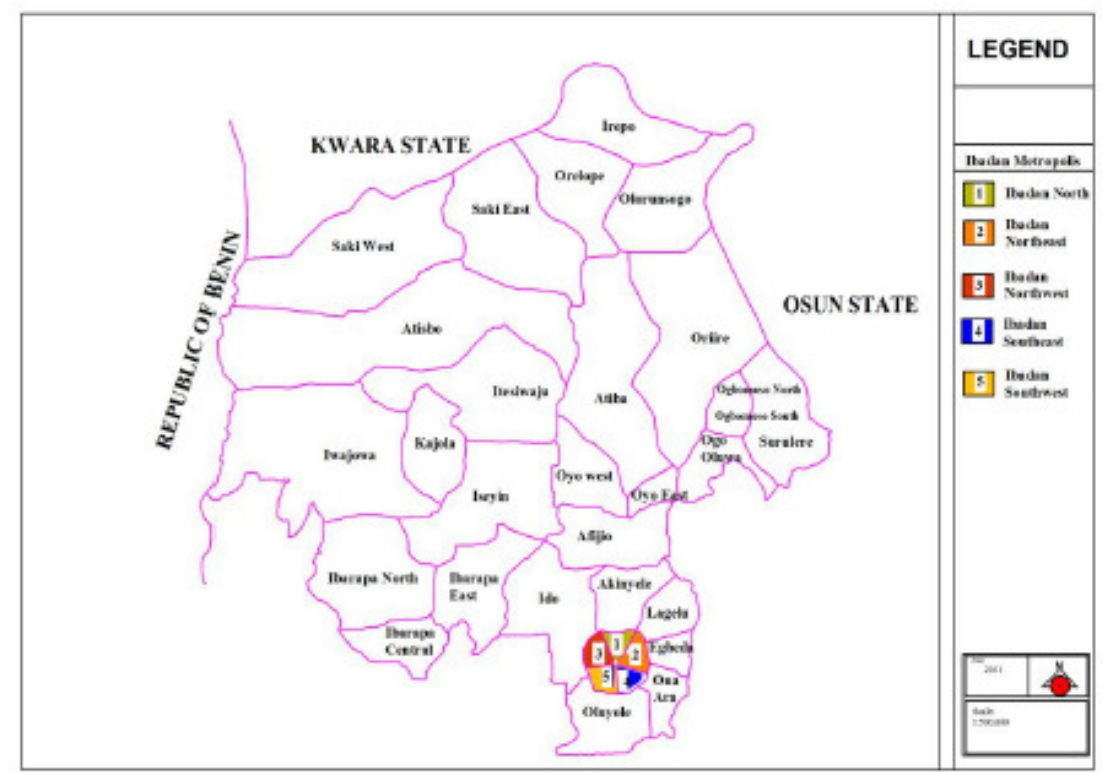

Figure 1: Map of Oyo State showing Ibadan Metropolis

\section{Methodology}

Data for this study was derived from both primary and secondary sources. The multi-stage sampling technique was adopted for this study. Therefore, political wards in the two (2) selected local governments (Ibadan Northeast and Ibadan Southwest) were stratified into high, medium and low density residential areas. From the stratification, fourteen 
(14), Five (5), and Five (5) wards were obtained in the high, medium and low density areas respectively. Two (2) political wards were randomly selected from each of the high, medium and low density areas of the selected local governments. Thus, a total six (6) political wards was selected for the study.

The sample size of buildings was drawn using systematic random sampling technique. In arriving at the sample size, the first residential building to be sampled in each political ward was chosen randomly. The sampling interval was one out of every twenty fifth (25th) housing units representing $4 \%$ of all the residential buildings in the six (6) political wards chosen for the survey. Since the total number of buildings in all the six (6) political wards selected was 10,703 , the sampled size (4\%) was 428 housing units amounting to 428 questionnaires. However, only 405 questionnaires was completed and returned for analysis. Because the unit of investigation is the landowner, a landowner was sampled from each of the residential building selected.

In an attempt to describe the variation in the residents' access to land for housing development in the study area, the linear regression technique was applied in the analysis. This technique is not only capable of handling the problem of interactions among the independent variables but also it enables us to know the contribution or importance of each variable (or linear composite of variable) to the explanation of variation in the dependent variable (land accessibility). It also allows the prediction of value of the dependent variable.

According to Bryman, et al. (1990) the equation of multiple regression of $\mathrm{y}$ (dependent variable) on $\mathrm{X}_{1}, \mathrm{X}_{2} \ldots \mathrm{Xn}$ (independent variables) is given as:

$$
\mathrm{Y}=\mathrm{a}+\mathrm{b} 1 \mathrm{x} 1+\mathrm{b} 2 \times 2
$$
bnxn+e
Where,

$X_{1}, X_{2} \ldots . X n$ are the independent variables. For this study the independent variables are

$\mathrm{b}_{1}, \mathrm{~b}_{2} \ldots$ bn are multiples regression coefficients for the independent variables (the slope of the regression line relative to $\mathrm{x}$-axis)

' $\mathrm{a}$ ' is an error term which points to the fact that a proportion of the variance in the dependent variable, $\mathrm{y}$ is unexplained by the regression equation.

$Y=a+B_{1} X_{1}+B_{2} X_{2}+B_{3} X_{3}+B_{4} X_{4}+$ $B_{5} X_{5}+B_{6} X_{6}+B_{7} X_{7}+B_{8} X_{8}+B_{9} X_{9}+$ $B_{10} X_{10}+B_{11} X_{11}+\mathrm{e}$

Where,

$Y=$ Land accessibility (Length of time taken to secure land)

$a=$ Constant

$B_{1}-B_{12}=$ Coefficients of determination of

$X_{1}-X_{12}$

$\mathrm{X} 1=$ Monthly income

$\mathrm{X} 2=$ Age of respondents

$\mathrm{X} 3=$ Gender of respondents

X4 = Marital status

$\mathrm{X} 5=$ years spent in pursuit of formal education

X6 $=$ Household size

$\mathrm{X} 7=$ Length of stay

$\mathrm{X} 8=$ Size of land

$\mathrm{X} 9=$ Time of land acquisition

$\mathrm{X} 10=$ Cost of land

$\mathrm{X} 11=$ Method of land acquisition

\section{Discussion}

In order to identify what effect the independent variables have on the dependent variable, coefficient of determination is considered. In multiple regressions, this effect is measured by the coefficient of multiple determinations ( $\mathrm{r} 2$ ), which is the ratio of the sum of squared due to regression to total sum of squares. The coefficient of multiple determination was used to compute the proportion of the variance of the dependent variable that is due to the combined effects of the 
independent variables. The regression analysis is undertaken to identify and determine the influence of some independent variables on key index of ownership and use of land in Ibadan metropolis. Therefore, the responses on the following determinants namely: income, length of time spent in the pursuit of formal education, household size, cost of land, time of acquisition of land, age among other factors were used as variables in the analysis.

\section{Residents' Land Accessibility in the High Density Area}

Table 1 shows the correlation matrix of the linear association between the households' characteristics; land characteristics and land accessibility in the high density area. The household and land characteristics were the independent variables while the dependent variable was land accessibility (length of time taken to secure land).

Many interesting results were obtained in the matrix. The coefficient that is \pm .500 or greater shows a high level of covariation between the variables involved. Also, coefficient ranging between \pm .300 and \pm .400 shows moderate level of correlation, while those between \pm .100 and \pm .200 indicates a weak level of correlation. Those lower than \pm .100 shows little or no linear correlation.

A thorough examination of the table in the high density areas revealed some point of interest. Contrary to expectation, income has a strong relationship with level of land access in the high density areas even as earlier findings revealed that most respondents in the high density areas earn less than N18, 000. The correlation score of .882 shows that as income increases the better the chances of gaining access to land. This implies that with higher income land access will improve regardless of the original owners of the land.
The score on the relationship between size of land and land access shows a high positive association with a figure of .717 . This means that the bigger the size of the land the more is the problem of gaining access to it. This might explain the small sizes of the land recorded in the high density areas. Also the relationship between education and accessibility to land recorded very high degree of positive relationship (.715). This implies that those who are more educated in the high density areas will have improved access to land compared to those whom are illiterates, though this might not be totally true in the high density areas where majority of the respondents have no formal education.

However, the relationship between the time the land was acquired and land access recorded a high negative correlation score of -.791. This implies that as the period in which land was acquired reduces the higher the level of accessibility to land. Similarly the increase in time of acquisition will tend to lead to decrease in land accessibility. This explained the reasons most respondents in the high density areas had easier access to land since most of them acquired their land before independence and before the promulgation of the Land Use Act of 1978.

The relationship between land accessibility and the followings also recorded high level of positive association: age (.504), household size (.581) and cost of land (.514). The implication of the above is that as respondents grow older the higher the accessibility to land; the higher the household size the higher the ease of gaining access to land while the cost of land will determine the impediment of gaining access to the land. There is weak relationship between gender and land access, length of stay and land accessibility while there is little or no relationship between marital status and land accessibility of the respondents in the high density areas. 
Ethiopian Journal of Environmental Studies and Management Vol. 9 (Suppl. 2) 2016

Table 1: Correlation Matrix of Land Accessibility Variables in High Density Area of Ibadan Metropolis

\begin{tabular}{|c|c|c|c|c|c|c|c|c|c|c|c|c|}
\hline & $\begin{array}{l}\text { Land } \\
\text { access }\end{array}$ & income & age & Gender & $\begin{array}{l}\text { Marital } \\
\text { status }\end{array}$ & education & $\begin{array}{l}\text { Household } \\
\text { size }\end{array}$ & $\begin{array}{l}\text { Length o } \\
\text { stay }\end{array}$ & $\begin{array}{l}\text { Size of } \\
\text { land }\end{array}$ & $\begin{array}{l}\text { Time land } \\
\text { was } \\
\text { acquired }\end{array}$ & $\begin{array}{l}\text { Cost of } \\
\text { land }\end{array}$ & $\begin{array}{l}\text { Method of land } \\
\text { acquisition }\end{array}$ \\
\hline Land access & 1.000 & & & & & & & & & & & \\
\hline Income & .882 & 1.000 & & & & & & & & & & \\
\hline Age & .504 & .523 & 1.000 & & & & & & & & & \\
\hline Gender & -.265 & -.387 & -.199 & 1.000 & & & & & & & & \\
\hline Marital status & -.070 & .027 & .378 & -.043 & 1.000 & & & & & & & \\
\hline Education & .715 & .775 & .838 & -.339 & .128 & 1.000 & & & & & & \\
\hline $\begin{array}{l}\text { Household } \\
\text { Size }\end{array}$ & .581 & .574 & .826 & -.334 & .223 & .867 & 1.000 & & & & & \\
\hline Length of stay & .384 & .475 & .741 & -.201 & .332 & .726 & .745 & 1.000 & & & & \\
\hline Size of land & .717 & .740 & .725 & -.269 & .056 & .861 & .722 & .545 & 1.000 & & & \\
\hline $\begin{array}{l}\text { Time land was } \\
\text { acquired }\end{array}$ & -.791 & -.811 & -.848 & .367 & -.194 & -.956 & -.885 & -.750 & -.855 & 1.000 & & \\
\hline Cost of land & .541 & .454 & .283 & .081 & .017 & .380 & .240 & .201 & .388 & -.390 & 1.000 & \\
\hline $\begin{array}{l}\text { Method of land } \\
\text { acquisition }\end{array}$ & -.002 & .017 & -.126 & -.078 & .173 & -.096 & -.107 & .116 & -.079 & -065 & -0.25 & 1.000 \\
\hline
\end{tabular}

Table 2 shows the statistics obtained from the regression equation between variables that determines the level of land accessibility in the high density areas. As could be observed from the Table the coefficient of determination $\left(\mathrm{r}^{2}\right)$ which states the proportion of the variation in the level of accessibility to land that is explained by the predictor variables is $88.6 \%$.

Table 2: The ANOVA value from the regression of land accessibility variables in the high density residential area of Ibadan Metropolis

\begin{tabular}{|c|c|c|c|c|c|c|c|}
\hline Model & $\mathrm{R}$ & $\mathrm{R}^{2}$ & $\begin{array}{l}\text { Sum of } \\
\text { square }\end{array}$ & Df & Mean squar & $\mathrm{F}$ & Sig \\
\hline $\begin{array}{l}\text { Regression } \\
\text { Residual } \\
\text { Total }\end{array}$ & .941 & .886 & $\begin{array}{l}71093.597 \\
9190.253 \\
80283.850\end{array}$ & $\begin{array}{l}11 \\
228\end{array}$ & $\begin{array}{l}6463.054 \\
40.308\end{array}$ & 160.341 & .000 \\
\hline
\end{tabular}

Predictors (constant): Household characteristics and Land attributes

Dependent variable: land accessibility

\section{Residents' Land Accessibility in the Medium Density Area}

Table 3 shows the correlation matrix of the linear association between the land accessibility variables and socio-economic variables in the medium density area. As revealed in the Table, the relationship between income and land accessibility shows the highest positive association with a figure of .859. Therefore improvement in income level is likely to result in improvement in land accessibility of respondents in the medium density area.

The correlation matrix also reveal that there is high positive relationship between length of stay in the area and access to land, household size and land accessibility, cost of land and accessibility to land, age and accessibility to land, size of the land and access to land and education and land accessibility, with a figure of $.846, .812$, $.808, .796, .777$, and .715 respectively. This implies that the duration of the stay in a particular urban centre is an important factor in influencing the residents' access to housing land. So that it could be concluded that the longer the period a resident stays the greater would be the effort that he/she would made to acquire housing land if he/she does not own it and if financial problem does not exist. The high positive score recorded between cost of land and land accessibility implies that the higher the cost the higher the value and the higher the difficulty of having access to such land. 
Also the very high degree of positive relationship between education and accessibility to land implies that those who are more educated in the medium density area will have improved access to land compared to those whom are less educated. However, the relationship between the time the land was acquired and land access recorded a high negative correlation score of -.798. This implies that as the period in which land was acquired has great impact on land accessibility because it is discovered that it is more difficult to acquire land presently than in the past.

Table 3: Correlation Matrix of Land Accessibility Variables in the Medium Density Area of Ibadan Metropolis

\begin{tabular}{|c|c|c|c|c|c|c|c|c|c|c|c|c|}
\hline & $\begin{array}{l}\text { Land } \\
\text { access }\end{array}$ & Income & Age & Gender & $\begin{array}{l}\text { Marital } \\
\text { status }\end{array}$ & Education & $\begin{array}{l}\text { Household } \\
\text { size }\end{array}$ & $\begin{array}{l}\text { Length o } \\
\text { stay }\end{array}$ & $\begin{array}{l}\text { Size of } \\
\text { land }\end{array}$ & $\begin{array}{l}\text { Time land } \\
\text { was } \\
\text { acquired }\end{array}$ & $\begin{array}{l}\text { Cost of } \\
\text { land }\end{array}$ & $\begin{array}{l}\text { Method of land } \\
\text { acquisition }\end{array}$ \\
\hline Land access & 1.000 & & & & & & & & & & & \\
\hline Income & .859 & 1.000 & & & & & & & & & & \\
\hline Age & .796 & .796 & 1.000 & & & & & & & & & \\
\hline Gender & -.369 & -.458 & -.190 & 1.000 & & & & & & & & \\
\hline Marital statu & .386 & .363 & .529 & -.071 & 1.000 & & & & & & & \\
\hline Education & .715 & .687 & .747 & -.217 & .455 & 1.000 & & & & & & \\
\hline $\begin{array}{l}\text { Household } \\
\text { Size }\end{array}$ & .812 & .841 & .610 & .534 & .260 & .648 & 1.000 & & & & & \\
\hline Length of stc & .846 & .824 & .607 & -.443 & .117 & .647 & .872 & 1.000 & & & & \\
\hline Size of land & .777 & .747 & .772 & -.231 & .535 & .612 & .636 & .650 & 1.000 & & & \\
\hline $\begin{array}{l}\text { Time land } \\
\text { was acquirec }\end{array}$ & -.798 & -.768 & -.860 & .220 & -.697 & -.748 & -.659 &.-558 & -.759 & 1.000 & & \\
\hline Cost of land & .808 & .815 & .566 & -.432 & .215 & .563 & .843 & .879 & .610 & -.592 & 1.000 & \\
\hline $\begin{array}{l}\text { Method of } \\
\text { land } \\
\text { acquisition }\end{array}$ & -.127 & .095 & -.042 & .162 & -.063 & -.105 & -.165 & -.192 & -.050 & .085 & -.265 & 1.000 \\
\hline
\end{tabular}

Table 4 shows the statistics obtained from the regression equation between socioeconomic variables, land use characteristics and land accessibility in the medium density area. Information from the table revealed that the coefficient of determination $\left(\mathrm{r}^{2}\right)$ which states the proportion of the variation in the level of accessibility to land that is explained by the predictor variables is $88.3 \%$.

Table 4: The ANOVA value from the regression of land accessibility variables in the medium density residential area of Ibadan Metropolis.

\begin{tabular}{|l|l|l|l|l|l|l|l|}
\hline Model & $\mathrm{R}$ & $\mathrm{R}^{2}$ & Sum of squar & $\mathrm{Df}$ & Mean square & $\mathrm{F}$ & Sig \\
\hline Regression & .940 & .883 & 237107.132 & 11 & 21555.194 & 76.079 & .000 \\
Residual & & & 9190.253 & 111 & 283.327 & & \\
Total & & & 80283.850 & 112 & & & \\
\hline
\end{tabular}

Predictors (constant): Household characteristics and Land attributes

Dependent variable: Land accessibility

\section{Residents' Land Accessibility in the Low Density Residential Area}

Table 5 shows the correlation matrix of the linear association between the land accessibility variables in the low density area. The Table revealed that there is high positive association between income and land accessibility with a figure of .843 . This implies that as income increases land accessibility increases. Also observed from the correlation matrix is the high positive correlation between age of the respondents and land accessibility with a figure of .885 . this goes a long way to 
show that as one increases in age the better the savings and the better the opportunity one has in gaining access to land since it was revealed that most respondents in the low density areas secured their land from government sources.

However, it was discovered that the relationship with household size and land accessibility recorded a high positive association with a score of .624, this can be regarded as a spurious correlation since it was discovered from the study that most respondents in the low density area have less than 4 persons in their household. Education level and access to land recorded high positive correlation of a figure of .614. This implies that the higher the education levels of the respondents the higher their access to land. The cost of land and land accessibility shows moderate level of association with a score of .373. This shows that the cost of land does not really have much impact on the level of access to land in the low density areas. Moreover, there is high positive association between education and size of the land with a figure of .603. This implies that the higher the educational attainment the higher the need for more space and the bigger the size of land that would be needed. However, the relationship between the time the land was acquired and land accessibility recorded a high negative correlation score of -.616.

Table 5: Correlation Matrix of Land Accessibility Variables in Low Density Area of Ibadan Metropolis

\begin{tabular}{|c|c|c|c|c|c|c|c|c|c|c|c|c|}
\hline & $\begin{array}{l}\text { Land } \\
\text { access }\end{array}$ & Income & Age & Gender & $\begin{array}{l}\text { Marital } \\
\text { status }\end{array}$ & Education & $\begin{array}{l}\text { Household } \\
\text { size }\end{array}$ & $\begin{array}{l}\text { Length c } \\
\text { stay }\end{array}$ & $\begin{array}{l}\text { Size of } \\
\text { land }\end{array}$ & $\begin{array}{l}\text { Time land } \\
\text { was } \\
\text { acquired }\end{array}$ & $\begin{array}{l}\text { Cost of } \\
\text { land }\end{array}$ & $\begin{array}{l}\text { Method of land } \\
\text { acquisition }\end{array}$ \\
\hline Land access & 1.000 & & & & & & & & & & & \\
\hline Income & 843 & 1.000 & & & & & & & & & & \\
\hline Age & .885 & .766 & 1.000 & & & & & & & & & \\
\hline Gender & -.301 & -.412 & -.160 & 1.000 & & & & & & & & \\
\hline Marital statu & .320 & .251 & .318 & -.051 & 1.000 & & & & & & & \\
\hline Education & .614 & .360 & .740 & .032 & .196 & 1.000 & & & & & & \\
\hline $\begin{array}{l}\text { Household } \\
\text { Size }\end{array}$ & .624 & .533 & .763 & -.128 & -.164 & .660 & 1.000 & & & & & \\
\hline Length of st: & .503 & .464 & .593 & -.131 & -.291 & .545 & .921 & 1.000 & & & & \\
\hline Size of land & .471 & .395 & .551 & .011 & .291 & .603 & .446 & .413 & 1.000 & & & \\
\hline $\begin{array}{l}\text { Time land } \\
\text { was acquirec }\end{array}$ & -.616 & -.464 & -.639 & .113 & -.699 & -.548 & -.154 & -.004 & .437 & 1.000 & & \\
\hline Cost of land & .373 & .189 & .266 & -.063 & .221 & .320 & -.042 & -.055 & .057 & -.475 & 1.000 & \\
\hline $\begin{array}{l}\text { Method of } \\
\text { land } \\
\text { acquisition }\end{array}$ & .324 & .191 & .315 & -.154 & 332 & .286 & .103 & .038 & .209 & -.349 & & 1.000 \\
\hline
\end{tabular}

Table 6 shows the statistics obtained from the regression equation between socioeconomic variables, land attributes and land accessibility in the low density areas. Information from the Table revealed that the coefficient of determination $\left(\mathrm{r}^{2}\right)$ which states the proportion of the variation in the level of accessibility to land that is explained by the predictor variables is $88.1 \%$.

Table 6: The ANOVA value from the regression of land accessibility variables in the low density residential area of Ibadan Metropolis

\begin{tabular}{|l|l|l|l|l|l|l|l|}
\hline Model & $\mathrm{R}$ & $\mathrm{R}^{2}$ & Sum of squar & $\mathrm{Df}$ & Mean squar & $\mathrm{F}$ & Sig \\
\hline Regression & .939 & .881 & 155569.023 & 11 & 14142.638 & 19.592 & .000 \\
Residual & & & 9190.253 & 29 & 721.869 & & \\
Total & & & 17650.220 & 40 & & & \\
\hline
\end{tabular}

Predictors (constant): Household characteristics and Land attributes

Dependent variable: land accessibility 
The extent of the strength of relationship is express by $\mathrm{R}$-square, which implies that every increase of 1(one) mark of socio-economic and land attributes leads to $88.6 \%$ in the high density areas, $88.3 \%$ in the medium density areas and $88.1 \%$ in the low density areas as depicted in Table 2, 4 and 6 respectively.

\section{Conclusion}

The study has examined the spatial variation in residents' accessibility to land for housing development in Ibadan metropolis and has discovered that there exist differences in the level of accessibility of residents' to land for housing development in the different residential zones in Ibadan.

The study has established that cost of land, time of acquisition of land, income, gender, age, size of the land and original owners of the land have strong relationship with the level of access to land in the high density areas.

Further, the study discovered that in the medium density area, income, length of stay in the area and the time of acquiring the land has strong relationship with the level of accessibility to land. Also, it can stated that with one's ability to pay, land accessibility is not difficult in the low density areas since majority of plots of land in the low density areas are located in approved layout.

Consequently, the study indicated that most land transactions and activities take place outside the formal land use planning mechanism created by the government. Informal land providers such as individuals and families are still very relevant in land use planning and management in the metropolis. Therefore, special consideration must be given to the factors influencing land accessibility in the study area. These factors will guide policy-makers in making sure that policies that would enhance land accessibility for all residents in the metropolis are enacted.

\section{References}

Ademiluyi, I and Raji, B. (2008). 'Public and Private Developers as Agents of Urban Housing in sub-Saharan Africa: the Situation in Lagos State', Humanity and Social Sciences Journal 3(2): 143-150.

Asiama, S.O. (1990). "Land for housing the urban poor in Africa - Some policy options," in Amis, $\mathrm{P}$ and Lloyd, P. (eds) Housing Africa's Urban Poor, Manchester University Press, Manchester, UK.

Bernstein, H. (2005). 'Rural Land and Land Conflicts in Sub-Saharan Africa', in S. Moyo and P. Yeros, eds., Reclaiming the Land: The Resurgence of Rural Movements in Africa, Asia and Latin America. London: Zed Books.

Burns, T. and Dalrymple, K. (2008). Conceptual Framework for Governance in Land Administration. International Federation of Surveyors. Article of the month, August 2008. www.fig.net/pub/monthly_articles/au gust_2008/august_2008_burns_dalry mple.html

CIA World Factbook (2016). http://www.indexmundi.com/nigeria/ demographic_profile.html. Accessed 02 nov. 2016

Djire, M. (2007). Land Registration in Mali. No land Ownership for Farmers?

Issue Paper No.144, International Ins titute for Environment and Development (IIED), London.

Egbu, A.U, Omolaiye, P. and Gameson, R. (2007). A quantitative model for 
assessing the impact of land use planning on urban housing development in Nigeria, International Development Planning Review, 29(2): 215-139.

EU (2004). Guidelines for Support to Land Design and Land Reform Processes in Developing countries. Final Draft for Consultation. Brussels: EU Task Force on Land Tenure.

Faye, J. (2008). Land and Decentralization in Senegal. Issue Paper No.149, International Institute.

Federal Ministry of Housing and Urban Development, (2006). Federal Land Information System (FELIS). A Handbook on FELIS. Abuja, Nigeria.

Garba, S.B. and Salisu, A.S. (1992). "Land Management and Strategies for Effective Urban Mass Housing in Nigeria". A paper presented at the Nigerian Institute of Quantity Surveyors Conference, Kaduna.

Goodman, R., Buxton, M., Chhetri, P., Schuerer, J., Taylor, E. and Wood, G. (2010). Planning reforms, Land Release and Supply of Housing. RMIT Research Centre. AHURI, Positioning Paper No 128.

Gurran, N., Milligan, V., Baker, D. and Bugg, L. (2008). International Practice in Planning for Affordable Housing: Lessons for Australia. AHURI Sydney and Queensland Research.

Hall, P. (2007). "Urban Land, Housing and Transportation: The Global Challenge", Global Urban Development Magazine 3 (1).

Jinadu, A.M. (2004). Undertaking the Basic Principle of Housing. King James Publishers, Minna, Nigeria.

Mabogunje, A.L. (2003). "Land Management in Nigeria: Issues, Opportunities and Threats". In Omirin, M.M. Nubi G.T. and
Fawehinmi, A.S., editors. Land Management and Property Taxation in Nigeria. Proceedings of a National Workshop Organized by the Department of Estate Management, University of Lagos, Akoka, Lagos, Nigeria. 13-31

Nuhu, M.S. (2008). "Public Land Policy, New Trends: Challenges in Nigerian Institutional Frameworks for State and Public Sector Land Management". FIG/FAO/CNG International Seminar on State and Public Sector Land Management Verona, Italy, September 9-10.

Oduwaye, A.O. (2001). Residential Land use and Land values in Metropolitan Lagos. Unpublished $\mathrm{PhD}$. Thesis, Urban and Regional Planning Department, Obafemi Awolowo University, Ile-Ife, Nigeria.

Okonkwo, C.M. (1986). "Structural and Operations of a Cooperative Core Housing", Paper presented in a seminar on Cooperative Core Housing: Methodology for Provision of Houses for Low and Middle income Groups, Organized by Anambra State Housing Corporation and the State Ministry of Works and Transport held in Enugu, $11^{\text {th }}-12^{\text {th }}$ September.

Omirin. M.M. (2002). "Issues in Land Accessibility in Nigeria". In Omirin M.M., Nubi, G.T. and Fawehinmi, A.S. editors. Land Management and Property Taxation in Nigeria. Proceedings of a National Workshop Organised by the department of Estate Management, University of Lagos, Akoka, Lagos, Nigeria. 4970 .

Onibokun, G.A. (1995). "Urban Land Ownership, Market and Development Process in Nigeria". Centre for African Settlement Studies and Development 
(CASSAD), Ibadan, Nigeria. Monograph Series 5.

Oruwari, Y. (2006). "Lest We Forget: The Poor People Need Housing in the Urban Areas in Nigeria Too. A reflection of Low-income Housing Provision" in A.I Okewole et al (eds.), The Built Environment: Innovation Policy and Sustainable Development, Ota,Nigeria: Department of Architecture, Covenant University, pages 2-9

United Nations (UN) (1994). 'Strategies to Implement Human Settlement
Policies on use change in Mashonal and provinces, Uppsala: Nordiska Afrika Instituent.

US Agency for International Development (USAID) (2004). "Land and Conflict- A Toolkit for Intervention", Washington D.C. USAID.

Williamson, I., Enemark, S., Wallace, J., and Rajabifard, A. (2010). Land Administration for Sustainable Development. ESRI Press, California. USA. 